\title{
Nanoparticles and cars - analysis of potential sources
}

\author{
Stefanie Uibel, Masaya Takemura, Daniel Mueller, David Quarcoo, Doris Klingelhoefer ${ }^{*}$ and David A Groneberg
}

\begin{abstract}
Urban health is potentially affected by particle emissions. The potential toxicity of nanoparticles is heavily debated and there is an enormous global increase in research activity in this field. In this respect, it is commonly accepted that nanoparticles may also be generated in processes occurring while driving vehicles. So far, a variety of studies addressed traffic-related particulate matter emissions, but only few studies focused on potential nanoparticles. Therefore, the present study analyzed the literature with regard to nanoparticles and cars. It can be stated that, to date, only a limited amount of research has been conducted in this area and more studies are needed to 1) address kind and sources of nanoparticles within automobiles and to 2) analyse whether there are health effects caused by these nanoparticles.
\end{abstract}

\section{Introduction}

Both outdoor and indoor air quality are important features that directly influence individual and public health both in occupational and environmental settings. Thus, numerous studies addressed these issues in the past [1-6]. In previous years a large number of studies focused on automobiles as sources for particulate matter. A few review articles address this issue [7-10]. In contrast, nanoparticle (NP) research has only touched the field of automobile industry at the periphery. So far, it is commonly accepted that NPs may be generated at the vehicle brake, the vehicle exhaust and at road-tire abrasion processes (Figure 1).

Since detailed reviews have not been performed so far, this article intends to summarize recently published data on nanoparticle research in relation to automobiles. Hence, this article deals with the kind of nanoparticles which may arise from traffic as well as their potential sources.

\section{Palladium nanoparticles: Solution-engineered NPs as a model for health effect studies of automotive particulate pollution}

A recent study by Wilkinson et al. addressed the use of solution-engineered palladium ( $\mathrm{Pd}$ ) nanoparticles as a model for health effect studies of automotive particulate

\footnotetext{
* Correspondence: occup-med@uni-frankfurt.de
Institute of Occupational, Social and Environmental Medicine,

* Correspondence: occup-med@uni-frankfurt.de
Institute of Occupational, Social and Environmental Medicine, Goethe-University, Frankfurt, Germany
}

pollution. The authors state that over $60 \%$ of platinum group metals (PGMs) ( $\mathrm{Ru}, \mathrm{Os}, \mathrm{Rh}, \mathrm{Ir}, \mathrm{Pd}$, and $\mathrm{Pt}$ ) are used for the production of automobile catalytic converters $[11,12]$. These converters are constructed by deposition of PGMs on a honeycomb-cordierite substrate covered by a washcoat of cordierite and $\gamma-\mathrm{Al}_{2} \mathrm{O}_{3}$ [11]. There may be health effects due to particles which are emitted from converters, but it is extremely difficult to generate PGM-NPs. Therefore, the authors sought an alternative for the production of these NPs by the use of solution synthesis [11] with the production of dispersions of hydrophilic spherical Pd nanoparticles (Pd-NPs) of uniform shape and size $(10.4 \pm 2.7 \mathrm{~nm})$ in one step by Bradley's reaction (solvothermal decomposition in an alcohol or ketone solvent). A similar approach also provided mixtures of Pd-NPs and nanoparticles of nonredox-active metal oxides, such as $\mathrm{Al}_{2} \mathrm{O}_{3}$. The authors furthermore studied particle aggregation in applied media by DLS and NP tracking analysis.

Three years earlier, a group from Munich reported the preparation and characterization of $\mathrm{Pd} / \mathrm{Al}_{2} \mathrm{O}_{3}$ and $\mathrm{Pd}$ nanoparticles as standardized test material for chemical and biochemical studies of traffic related emissions [13]. Specifically, two series of Pd particles were prepared: Pd NPs with 2-4 $\mathrm{nm}$ dispersed on aluminium oxide particles of a diameter range between 0.1 to $30 \mu \mathrm{m}$ and "Pd-only" NPs of 5-10 $\mathrm{nm}$ in diameter [13]. The Pd/ alpha- $\mathrm{Al}_{2} \mathrm{O}_{3}$ particles were reported to be very similar to particles emitted from catalytic converters by mechanical 


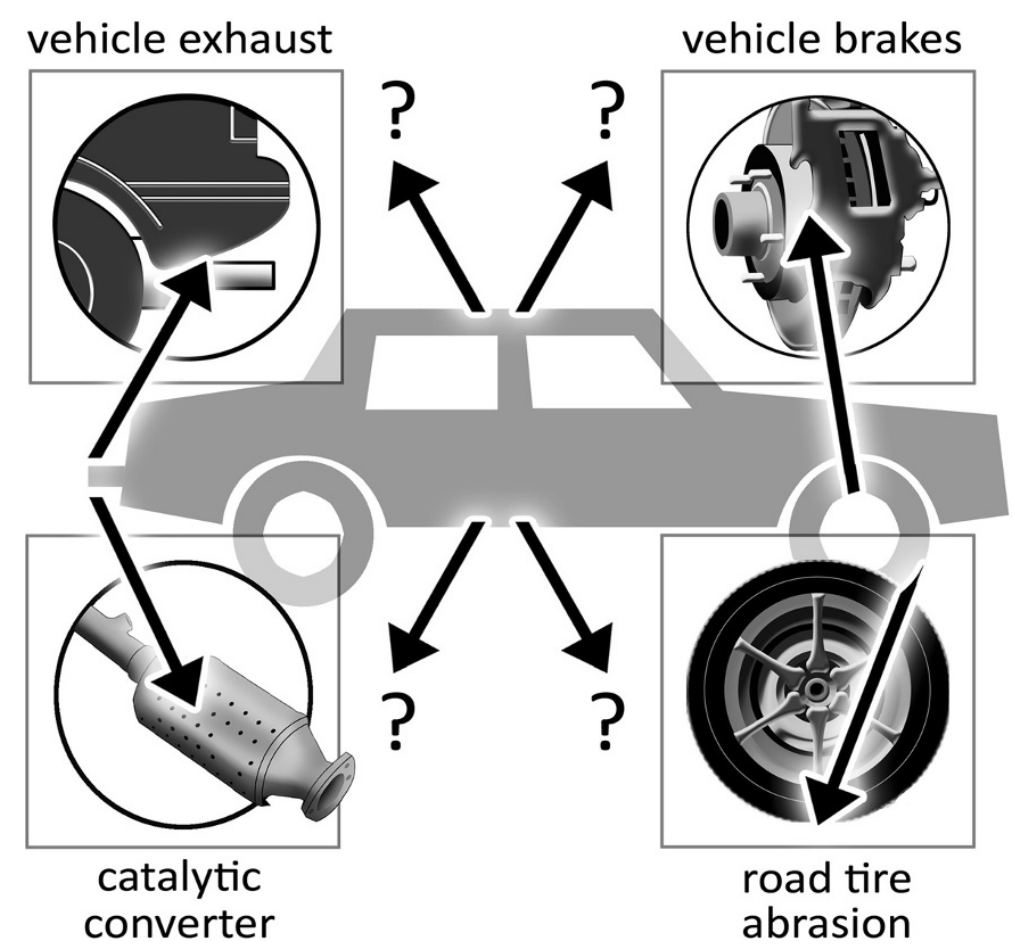

Figure 1 Generation of nanoparticles at different automobile stages.

abrasion. The Pd-only particles were suggested to be useful e.g. for exposure studies in which the presence of aluminium could lead to interferences when studying biological and biochemical effects [13]. In contrast to the study by Leopold et al. who characterized the NPs using transmission electron microscopy (TEM), high resolution transmission electron microscopy (HRTEM), selective area diffraction (SAD), laser granulometry and graphite furnace atomic absorption spectrometry (GFAAS) for the measurement of Pd concentrations [13], the group of Wilkinson et al. also performed toxicological experiments in order to assess putative health effects of the produced Pd NPs and nanocomposite mixtures. For this purpose, they used human primary bronchial epithelial cells (PBEC) and human alveolar carcinoma cell line (A549) as model system for NP-exposure [11]. They reported that a cellular uptake of Pd nanoparticles was only visible in PBEC, as determined by TEM. However, they found pronounced and dose-dependent effects on cellular secretion of soluble biomarkers both in PBECs and A549 cells and a decreased responsiveness of human epithelial cells to the pro-inflammatory cytokine TNF- $\alpha$ [11]. Interestingly, when cells were incubated with higher doses of the Pd nanoparticles, induction of apoptosis and caspase activation were observed present in PBEC but not in A549 cells [11]. In summary, the authors concluded that this mode of Pd NP generation is applicable to study the effects of Pd NPs. It is important to realize that this study cannot be used for an exact toxicological assessment for traffic-related health effects of Pd NPs since it is too preliminary.

\section{Gold nanoparticles: Subchronic inhalation toxicity studies}

Besides the use of gold nanoparticles (NPs) in cosmetics, food packaging, beverages, toothpaste, and lubricants, they may also be present in automobiles [14]. Since only a few studies have reported data on the toxicology of gold NPs so far, Sung et al. recently performed subchronic inhalation studies of gold nanoparticles in Sprague Dawley rats [14]. Next to a control group, a low-dose $\left(2.36 \times 104\right.$ particle $\left./ \mathrm{cm}^{3}, 0.04 \mu \mathrm{g} / \mathrm{m}^{3}\right)$, a middledose $\left(2.36 \times 105\right.$ particle $\left./ \mathrm{cm}^{3}, 0.38 \mu \mathrm{g} / \mathrm{m}^{3}\right)$, and a highdose $\left(1.85 \times 106\right.$ particle $\left./ \mathrm{cm}^{3}, 20.02 \mu \mathrm{g} / \mathrm{m}^{3}\right)$ group of animals were exposed for 6 hours/day, 5 days/week, for 90-days in a whole-body inhalation chamber. The average diameter of the gold NPs was 4-5 nm. The authors studied mortality and observed clinical symptoms, body weight, food consumption, and lung function on a weekly basis. Also, necropsy and blood and bronchoalveolar lavage sample analysis were performed at the end of the exposure protocol [14].

The authors reported that within the lung function tests, tidal volume and minute volume showed a tendency - but no significancy - to decrease comparing control and dose groups during the 90-days of exposure 
[14]. Also, no statistically significant differences were present in cellular differential counts. The microscopic analysis showed an inflammatory infiltrate with a mixed cell type, and increased macrophages in the high-dose group of exposed animals [14]. The tissue distribution analysis demonstrated a dose-dependent accumulation of gold in the lungs and the kidneys [14]. Interestingly, there was a gender-related difference in gold NP content in the kidneys present. The authors conclude that the lungs were the only organ in which dose-related changes in both male and female rats were observed [14].

\section{Particles released from low-metallic automotive brakes}

In April 2011, Kukutschová et al. reported a study that focussed on wear particles released from commercially available "low-metallic" automotive brake pads which were subjected to brake dynamometer tests in the experiments [15]. They determined particle size distribution in situ and collected the generated particles for further studies. The collected fractions and the original bulk material were analyzed using a multitude of techniques and it was found that airborne wear particles with sizes between $10 \mathrm{~nm}$ and $20 \mu \mathrm{m}$ were released into the air during the experiments. Interestingly, the numbers of nanoparticles $(<100 \mathrm{~nm})$ were by three orders of magnitude larger in comparison to the number of microparticles [15].

Concerning the temperature, the authors stated that size distribution of airborne wear particles generated during brake dynamometer simulations representing sub-urban driving segments varies in dependence on temperature of the friction surface [15]. They found that the generation of wear particles smaller than $500 \mathrm{~nm}$ was negligible for cold surfaces, while the concentration of nano-sized particles $(<100 \mathrm{~nm})$ gradually increased when the bulk temperature of the rotor approached approximately $300{ }^{\circ} \mathrm{C}$. They also reported that thermal analysis of milled bulk brakes performed in oxidative and inert atmospheres showed a heterogeneous ignition mechanism of carbonaceous particles [15]. The ignition temperature is approximately $300{ }^{\circ} \mathrm{C}$, which correlates with the rotor temperature when the maximum number of finest particles was generated [15].

In total, the analysed friction composite was a multicomponent heterogeneous material. However, the dominant elements in the finest wear particle fractions were $\mathrm{Fe}$ and $\mathrm{C}$. It was not easy to distinguish $\mathrm{Cu}, \mathrm{Sn}$ and other metals/oxides in diffraction measurement. Further PIXE analysis revealed the presence of $\mathrm{Fe}, \mathrm{Cu}, \mathrm{Sn}, \mathrm{Zn}$ and $\mathrm{S}$ in all fractions [15].

Wear particle analysis was performed using Raman microspectroscopy and showed the presence of carbon black and graphitic particles. Also, TEM-diffraction analysis identified the presence of maghemite $\left(\gamma-\mathrm{Fe}_{2} \mathrm{O}_{3}\right)$, magnetite $\left(\mathrm{FeO} \cdot \mathrm{Fe}_{2} \mathrm{O}_{3}\right)$ and hematite $\left(\alpha-\mathrm{Fe}_{2} \mathrm{O}_{3}\right)$ in collected nano fractions. All wear particle fractions contained nano-sized particles down to $20 \mathrm{~nm}$ in diameter in the form of agglomerates [15].

The authors concluded that wear of low-metallic friction composite produces airborne NPs. These NPs contain carbon black and a variety of metallic compounds (Figure 2). It needs to be stated that a comprehensive evaluation of particles which contribute to air pollution as presently performed requires a combination of several microscopic techniques and chemical analyses to determine the real size of individual particles present in particulate matter [15].

\section{Organometallic fuel additives and nanoparticle emissions from gasoline passenger cars}

Gidney and colleagues stated in their recent article that the European particle measurement program (PMP) and the new EURO 6 regulations on particle emissions from diesel cars were intended to promote the use of diesel particulate filters (DPFs) but excluded particles smaller than $23 \mathrm{~nm}$ because of measurement difficulties in that size range [16]. However, these regulations do not imply that particles below $23 \mathrm{~nm}$ are benign and to clarify the fate of organometallic gasoline fuel additives from a gasoline engines, the authors studied particulate number and size distributions in the exhaust line of a typical European family passenger car with a $1.6 \mathrm{~L}$ four cylinder spark ignition engine (multi point injection, 4 cylinder, $1.6 \mathrm{~L}$ displacement, catalyst volume $1.66 \mathrm{~L}$, European Stage 3 emissions standards) fuelled with standard gasoline and gasoline containing an organometallic additives [16]. Three additives were tested: $\mathrm{CH}_{3} \mathrm{C}_{5} \mathrm{H}_{4} \mathrm{Mn}$ $(\mathrm{CO})_{3}, \mathrm{Fe}(\mathrm{Cp})_{2}$ and $\mathrm{PbEt}_{4}$. Two concentrations of $\mathrm{CH}_{3} \mathrm{C}_{5} \mathrm{H}_{4} \mathrm{Mn}(\mathrm{CO})_{3}$ were used, $8.3 \mathrm{mg} / \mathrm{L}$ (Mn-8) and $18 \mathrm{mg} / \mathrm{L}$ (Mn-18) of manganese. These concentrations represent levels that were historically permitted in the U.S. and Canada, respectively. One concentration was used for the $\mathrm{FeCp}_{2}$ and $\mathrm{PbEt}_{4}$ tests $(\mathrm{Fe}-8-8.4 \mathrm{mg} / \mathrm{L}$ and $\mathrm{Pb}-30-31.3 \mathrm{mg} / \mathrm{L}$ ). This was the same concentration of metal in the fuel as the Mn-8 case [16]. They measured particle size on the exhaust of a car operating on a chassis dynamometer fuelled with standard gasoline and gasoline containing low levels of $\mathrm{Pb}, \mathrm{Fe}$, and $\mathrm{Mn}$ organometallic additives. Interestingly, when additives were present in the experimental setup, there was a distinct nucleation mode consisting primarily of sub-10 nm nanoparticles [16]. It was found that at equal molar dosing $\mathrm{Mn}$ and $\mathrm{Fe}$ gave similar NP concentrations at the tailpipe, whereas $\mathrm{Pb}$ gave a considerably lower concentration. In further experiments the authors used a catalytic stripper in order to remove the organic component of these particles. It was shown that they were mainly 


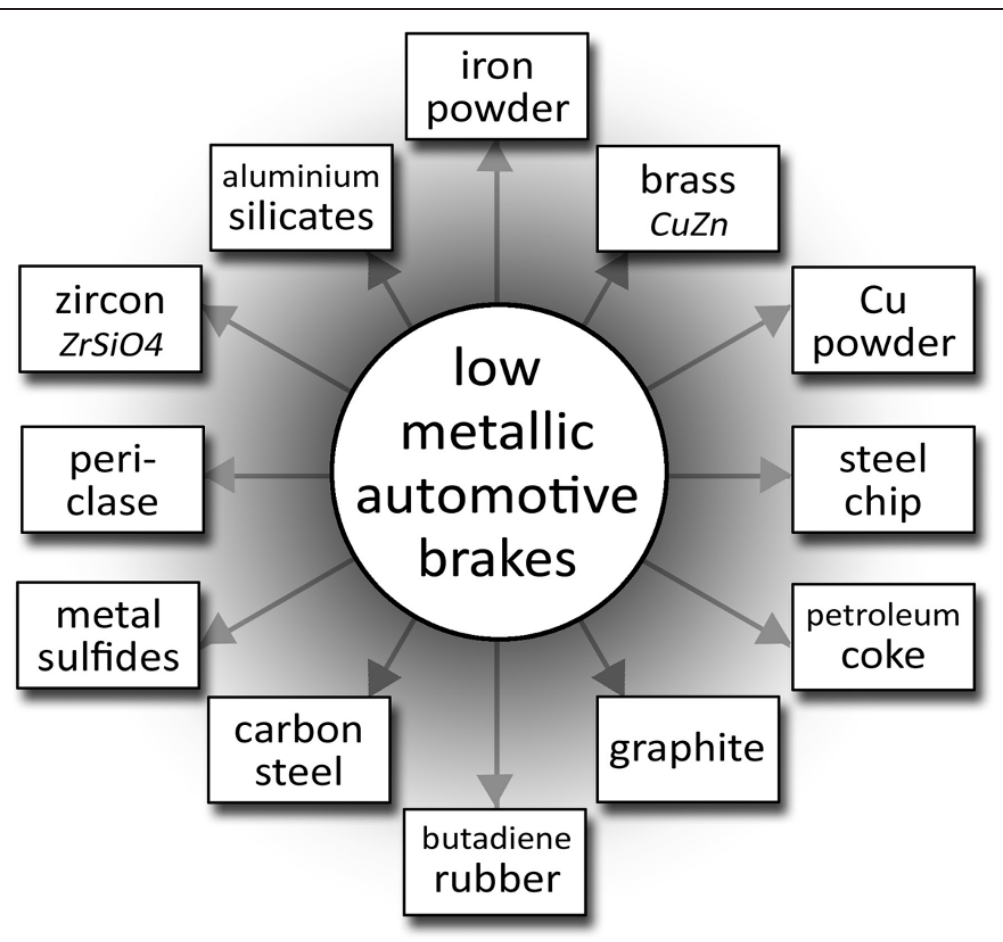

Figure 2 Easily detectable constituents in the bulk brake lining sample as reported by Kukutschová et al. [15].

solid and, because of their association with inorganic additives, presumably inorganic [16].

The authors stated that solid nucleation mode NPs of similar size and concentration to those observed in the present study from a gasoline engine with $\mathrm{Mn}$ and $\mathrm{Fe}$ additives have also been observed from modern heavyduty diesel engines without after-treatment at idle, but these solid particles are a small fraction of the primarily volatile nucleation mode particles emitted [16]. The authors suggested that solid nucleation mode particles emitted by the diesel engines are likely derived from metal compounds in the lubrication oil, although carbonaceous particles cannot be ruled out. They also stated that most of these solid nanoparticles emitted by both engine types fall below the $23 \mathrm{~nm}$ cutoff of the PMP number regulation.

\section{Conclusion}

In view of the current research on nanoparticles, it needs to be stated that the amount of published articles on nanoparticles, which may arise from traffic, is still largely limited. Therefore, modern scientometric tools which are in use for the analysis of other research fields are not applicable in this area [17-29].

As a conclusion, there is a lack of information present regarding a) levels of nanoparticles that are emitted from automobiles b) effects of nanoparticles with regard to the emission levels. There are numerous approaches present which may bring light into this field of environmental sciences. Specifically, sources and levels of different NPs need to be identified and analyzed. Additionally, further toxicological research should be performed about molecular mechanisms, i.e. with the use of advanced techniques of biochemistry [30-33] and molecular biology [34-38].

\section{Competing interests}

The authors declare that they have no competing interests.

\section{Acknowledgement}

We thank G. Volante for expert help. Publication of this review was partly supported by DFG.

\section{Authors' contributions}

SU, MT, DM, DQ, DK, DAG have made substantial contributions to the conception and design of the review, acquisition of the review data and have been involved in drafting and revising the manuscript. All authors have read and approved the final manuscript.

Received: 11 May 2012 Accepted: 22 June 2012

Published: 22 June 2012

\section{References}

1. Groneberg DA, Fischer A: Occupational medicine and toxicology. J Occup Med Toxicol 2006, 1:1.

2. Elfman L, Riihimaki M, Pringle J, Walinder R: Influence of horse stable environment on human airways. J Occup Med Toxicol 2009, 4:10.

3. Groneberg DA, Nowak D, Wussow A, Fischer A: Chronic cough due to occupational factors. J Occup Med Toxicol 2006, 1:3.

4. Sierra-Vargas MP, Guzman-Grenfell AM, Blanco-Jimenez S, SepulvedaSanchez JD, Bernabe-Cabanillas RM, Cardenas-Gonzalez B, Ceballos G, Hicks JJ: Airborne particulate matter PM2.5 from Mexico City affects the generation of reactive oxygen species by blood neutrophils from asthmatics: an in vitro approach. J Occup Med Toxicol 2009, 4:17. 
5. Groneberg DA, Scutaru C, Lauks M, Takemura M, Fischer TC, Kolzow S, van Mark A, Uibel S, Wagner U, Vitzthum K, et al: Mobile Air Quality Studies (MAQS)-an international project. J Occup Med Toxicol 2010, 5:8.

6. Groneberg-Kloft B, Kraus T, Mark A, Wagner U, Fischer A: Analysing the causes of chronic cough: relation to diesel exhaust, ozone, nitrogen oxides, sulphur oxides and other environmental factors. J Occup Med Toxicol 2006, 1:6

7. de Kok TM, Driece HA, Hogervorst JG, Briede JJ: Toxicological assessment of ambient and traffic-related particulate matter: a review of recent studies. Mutat Res 2006, 613:103-122

8. Thorpe A, Harrison RM: Sources and properties of non-exhaust particulate matter from road traffic: a review. Sci Total Environ 2008, 400:270-282.

9. Bhaskaran K, Hajat S, Haines A, Herrett E, Wilkinson P, Smeeth L: Effects of air pollution on the incidence of myocardial infarction. Heart 2009, 95:1746-1759.

10. Amato F, Querol X, Johansson C, Nagl C, Alastuey A: A review on the effectiveness of street sweeping, washing and dust suppressants as urban PM control methods. Sci Total Environ 2010, 408:3070-3084.

11. Wilkinson KE, Palmberg L, Witasp E, Kupczyk M, Feliu N, Gerde P, Seisenbaeva GA, Fadeel B, Dahlen SE, Kessler VG: Solution-Engineered Palladium Nanoparticles: Model for Health Effect Studies of Automotive Particulate Pollution. ACS Nano 2011, 5:5312-5324

12. Ravindra K, Bencs L, Van Grieken R: Platinum group elements in the environment and their health risk. Sci Total Environ 2004, 318:1-43.

13. Leopold K, Maier M, Schuster M: Preparation and characterization of $\mathrm{Pd} / \mathrm{Al} 2 \mathrm{O} 3$ and $\mathrm{Pd}$ nanoparticles as standardized test material for chemical and biochemical studies of traffic related emissions. Sci Total Environ 2008, 394:177-182.

14. Sung JH, Ji JH, Park JD, Song MY, Song KS, Ryu HR, Yoon JU, Jeon KS, Jeong J, Han BS, et al: Subchronic inhalation toxicity of gold nanoparticles. Part Fibre Toxicol 2011, 8:16

15. Kukutschova J, Moravec P, Tomasek V, Matejka V, Smolik J, Schwarz J, Seidlerova J, Safarova K, Filip P: On airborne nano/micro-sized wear particles released from low-metallic automotive brakes. Environ Pollut 2011, 159:998-1006.

16. Gidney JT, Twigg MV, Kittelson DB: Effect of organometallic fuel additives on nanoparticle emissions from a gasoline passenger car. Environ Sci Technol 2010, 44:2562-2569.

17. Vitzthum K, Scutaru C, Quarcoo D, Mache S, Groneberg DA, Schoffel N: Cardiac insufficiency: a critical analysis of the current publication procedures under quantitative and qualitative aspects. J Cardiothorac Vasc Anesth 2010, 24:731-734

18. Groneberg-Kloft B, Fischer TC, Quarcoo D, Scutaru C: New quality and quantity indices in science (NewQIS): the study protocol of an international project. J Occup Med Toxicol 2009, 4:16.

19. Vitzthum K, Scutaru C, Musial-Bright L, Quarcoo D, Welte T, Spallek M, Groneberg-Kloft B: Scientometric analysis and combined densityequalizing mapping of environmental tobacco smoke (ETS) research. PLoS One 2010, 5:e11254.

20. Groneberg-Kloft B, Kreiter C, Welte T, Fischer A, Quarcoo D, Scutaru C: Interfield dysbalances in research input and output benchmarking: visualisation by density equalizing procedures. Int J Health Geogr 2008 7:48.

21. Scutaru C, Quarcoo D, Takemura M, Welte T, Fischer TC, Groneberg-Kloft B: Density-equalizing mapping and scientometric benchmarking in Industrial Health. Ind Health 2010, 48:197-203.

22. Groneberg-Kloft B, Quarcoo D, Scutaru C: Quality and quantity indices in science: use of visualization tools. EMBO Rep 2009, 10:800-803.

23. Scutaru C, Quarcoo D, Sakr M, Shami A, Al-Mutawakel K, Vitzthum K, Fische TC, Zuberbier T, Groneberg-Kloft B: Density-equalizing mapping and scientometric benchmarking of European allergy research. J Occup Med Toxicol 2010, 5:2

24. Groneberg-Kloft B, Scutaru C, Dinh QT, Welte T, Chung KF, Fischer A, Quarcoo D: Inter-disease comparison of research quantity and quality: bronchial asthma and chronic obstructive pulmonary disease. J Asthma 2009, 46:147-152.

25. Kusma B, Scutaru C, Quarcoo D, Welte T, Fischer TC, Groneberg-Kloft B: Tobacco control: visualisation of research activity using densityequalizing mapping and scientometric benchmarking procedures. Int J Environ Res Public Health 2009, 6:1856-1869.
26. Groneberg-Kloft B, Scutaru C, Fischer A, Welte T, Kreiter C, Quarcoo D: Analysis of research output parameters: density equalizing mapping and citation trend analysis. BMC Health Serv Res 2009, 9:16.

27. Borger JA, Neye N, Scutaru C, Kreiter C, Puk C, Fischer TC, Groneberg-Kloft B: Models of asthma: density-equalizing mapping and output benchmarking. J Occup Med Toxicol 2008, 3(Suppl 1):S7.

28. Groneberg-Kloft B, Scutaru C, Kreiter C, Kolzow S, Fischer A, Quarcoo D: Institutional operating figures in basic and applied sciences: Scientometric analysis of quantitative output benchmarking. Health Res Policy Syst 2008, 6:6.

29. Zell H, Quarcoo D, Scutaru C, Vitzthum K, Uibel S, Schoffel N, Mache S, Groneberg DA, Spallek MF: Air pollution research: visualization of research activity using density-equalizing mapping and scientometric benchmarking procedures. J Occup Med Toxicol 2010, 5:5.

30. Groneberg DA, Peiser C, Dinh QT, Matthias J, Eynott PR, Heppt W, Carlstedt I, Witt C, Fischer A, Chung KF: Distribution of respiratory mucin proteins in human nasal mucosa. Laryngoscope 2003, 113:520-524.

31. Eynott PR, Paavolainen N, Groneberg DA, Noble A, Salmon M, Nath P, Leung SY, Chung KF: Role of nitric oxide in chronic allergen-induced airway cell proliferation and inflammation. J Pharmacol Exp Ther 2003, 304:22-29.

32. Groneberg DA, Bester C, Grutzkau A, Serowka F, Fischer A, Henz BM, Welke $P$ : Mast cells and vasculature in atopic dermatitis-potential stimulus of neoangiogenesis. Allergy 2005, 60:90-97.

33. Peiser C, Springer J, Groneberg DA, McGregor GP, Fischer A, Lang RE: Leptin receptor expression in nodose ganglion cells projecting to the rat gastric fundus. Neurosci Lett 2002, 320:41-44.

34. Dinh QT, Groneberg DA, Peiser C, Springer J, Joachim RA, Arck PC, Klapp BF, Fischer A: Nerve growth factor-induced substance $P$ in capsaicininsensitive vagal neurons innervating the lower mouse airway. Clin Exp Allergy 2004, 34:1474-1479.

35. Groneberg DA, Doring F, Nickolaus M, Daniel H, Fischer A: Expression of PEPT2 peptide transporter mRNA and protein in glial cells of rat dorsal root ganglia. Neurosci Lett 2001, 304:181-184.

36. Dinh QT, Groneberg DA, Peiser C, Mingomataj E, Joachim RA, Witt C, Arck PC, Klapp BF, Fischer A: Substance P expression in TRPV1 and trkApositive dorsal root ganglion neurons innervating the mouse lung. Respir Physiol Neurobiol 2004, 144:15-24

37. Lauenstein HD, Quarcoo D, Plappert L, Schleh C, Nassimi M, Pilzner C, Rochlitzer S, Brabet P, Welte T, Hoymann HG, et al: Pituitary adenylate cyclase-activating peptide receptor 1 mediates anti-inflammatory effects in allergic airway inflammation in mice. Clin Exp Allergy 2011, 41:592-601.

38. Groneberg DA, Fischer A, Chung KF, Daniel H: Molecular mechanisms of pulmonary peptidomimetic drug and peptide transport. Am J Respir Cell Mol Biol 2004, 30:251-260.

doi:10.1186/1745-6673-7-13

Cite this article as: Uibel et al:: Nanoparticles and cars - analysis

of potential sources. Journal of Occupational Medicine and Toxicology 2012 7:13.

\section{Submit your next manuscript to BioMed Central and take full advantage of:}

- Convenient online submission

- Thorough peer review

- No space constraints or color figure charges

- Immediate publication on acceptance

- Inclusion in PubMed, CAS, Scopus and Google Scholar

- Research which is freely available for redistribution 